\title{
Assessment of Physico-Chemical Parameters of Water in Kashmir Region with Reference to Dal Lake
}

\author{
Javaid Fayaz Lone ${ }^{1}$, Akhtar Rasoo ${ }^{2^{\star}}$ and Syeda Azeem Unnisa ${ }^{2}$ \\ ${ }^{1}$ School of Studies in Botany, Jiwaji University Gwalior, Madhya Pradesh, India \\ ${ }^{2}$ Department of Environmental Science, Osmania University, Hyderabad, India
}

\begin{abstract}
The Present study was aimed to estimate and investigate some physico-chemical parameters of Dal Lake of Kashmir, India. During the present study water samples from five basins were collected and analyzed for the physicochemical properties. Analysis showed a great variation in water quality among the different basins. Much polluted basins i.e., Telebal and Jogilankar are having deteriorated water qualities and possible reason for this could be the increasing eutrophication resulting from agricultural practices in the nearby catchment area or tourism activity.
\end{abstract}

Keywords: Dal Lake; Anthropogenic activities; Basins; Physicochemical parameters

\section{Introduction}

Kashmir valley is famous for its scenic beauty, with biodiversity, throughout the world. The rich aquatic resources, in the form of fresh lakes, rivers, springs etc., are of great importance. Dal Lake is world famous Kashmir's pride renowned as Srinagar's Jewel. It is an urban valley lake of fluvioglacial as well as fluviatile origin, situated at an altitude of $1800 \mathrm{~m}$ (ASL) between $34^{\circ} 5^{\prime}-34^{\circ} 7^{\prime} \mathrm{N}$ latitude and $74^{\circ} 8^{\prime}$ $74^{\circ} 9^{\prime}$ E longitudes, in the heart of Kashmir Valley, on the North-East of the state at the foot of Zabarwan hills. The total water surface area of the lake is $11.45 \mathrm{~km}^{2}$, of which $4.1 \mathrm{~km}^{2}$ is floating gardens, $1.51 \mathrm{~km}^{2}$ and $2.25 \mathrm{~km}^{2}$ are land and marsh respectively [1]. During the winters, the upper layer of lake usually freezes when temperature goes down to $10^{\circ} \mathrm{C}$. Dal Lake is the second largest lake in the valley meant for tourism and recreation and is considered as main tourist hub in the entire Kashmir valley. Average annual rainfall recorded is $655 \mathrm{~mm}$. During summer season, snow melts in the higher catchments which results in maximum discharge in Dachigam and Dara inlet which flows into the Dal Lake. A perennial inflow channel known as Telebalinlet enters the lake from the north and supplies 80 percent of water from high altitude lake called Marsar Lake [2]. Within the lake basin itself there are number of springs acting as permanent water source to the lake [3]. The main contributors towards the degradation in the physico-chemical properties of water quality of Dal Lake are land use changes, increasing urbanization, use of various chemicals for agricultural practices in the catchment areas, soil erosion, restaurants and hotels located nearby, which is one or other way discharge the sewage and garbage, organic as well as inorganic effluents into water body thereby deteriorate the quality of water. The increase in nutrient concentration results in hyper-eutrophication which disturbs the entire aquatic ecosystem. During the past few years, concern is being voiced by both public as well as state Govt. over the dying and deteriorating condition of Dal Lake [4]. Keeping in view, the ecological significance of Dal Lake in Kashmir, the present work was carried out.

\section{Material and Methods}

\section{Study sites}

The present work were carried out during 2014 in five sites/basins of Dal Lake Kashmir viz.

(1) Telebal basin (TB basin North side)

(2) Jogilankar basin (South West side)
(3) Nishat basin (East side)

(4) Nigeen basin (North West side)

(5) NehruPark basin (NP basin South side)

Telebal basin is situated in North side and shallow, open drainage lake is fed by Telebal inlet. The complex land use pattern is reflected in this area, with fields of paddy, orchards and gardens in the lower slopes, and barren hills in upper side. Jogilankar basin is situated in the SouthWest side of the lake and huge regular municipal solid waste is disposed off into the lake by the inhabitants through drainage. Nishat basin is situated in the East side of lake which is also a tourist spot associated with famous Mughal gardens and restaurants. Nigeen basin is situated in North-West side of the lake where huge agricultural practices are going on through-out the year. The Nehru park basin is the busiest tourist spot situated in the East side of lake. There are many hotels in the nearby side and people enjoy rides on shikaras, living in houseboats etc. (Figure 1).

\section{Sample collection}

Water samples were collected from the surface of above five basins during daytime in 2014

The following physico-chemical properties were estimated (Table 1).

\section{Results and Discussion}

A perusal of data present in Table 2 and Figure 2 clearly shows maximum $\mathrm{pH} 7.1$ in Nehru park basin and the minimum was observed in Nishat basin (4.5), the decrease in $\mathrm{pH}$ may be due to efficient utilization of phosphorus by macrophytic vegetation in the lake [5]. In the other three sites viz Telebal basin, Jogilankar basin, and Nigeen basin $\mathrm{pH}$ ranges from 6.4 to 6.9 (Table 2 and Figure 2). Electric conductivity i.e., capacity of water to carry the electric current depends upon the quantity of

*Corresponding author: Akhtar Rasool, Department of Environmental Science, Osmania University, Hyderabad, India, E-mail: akhtarrasool01@gmail.com

Received July 13, 2016; Accepted February 17, 2017; Published February 20 2017

Citation: Lone JF, Rasoo A, Unnisa SA (2017) Assessment of Physico-Chemical Parameters of Water in Kashmir Region with Reference to Dal Lake. J Environ Anal Toxicol 7: 435. doi: 10.4172/2161-0525.1000435

Copyright: (c) 2017 Lone JF, et al. This is an open-access article distributed under the terms of the Creative Commons Attribution License, which permits unrestricted use, distribution, and reproduction in any medium, provided the original author and source are credited. 


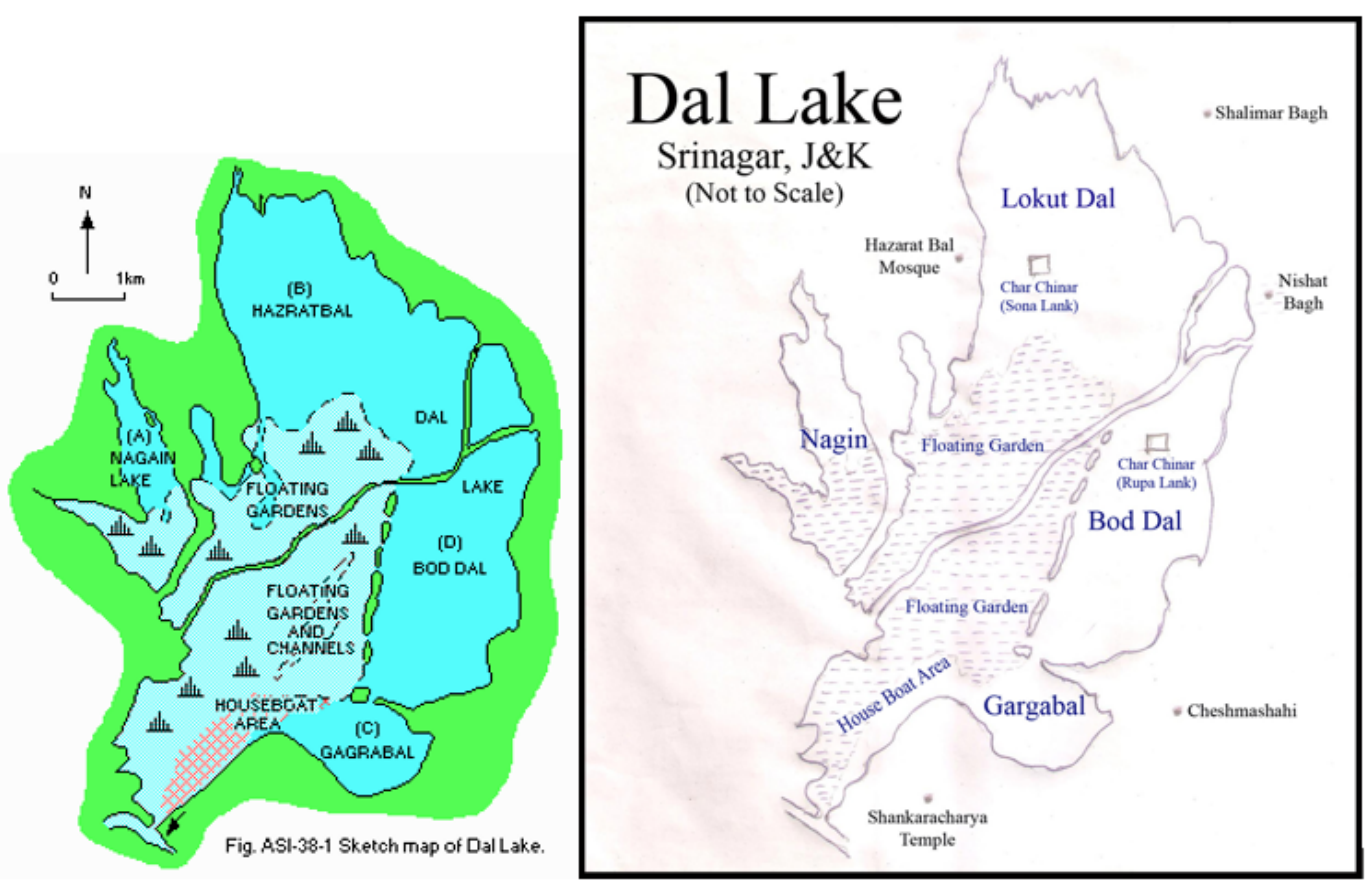

Figure 1: Map not to scale.

\begin{tabular}{|c|c|}
\hline Parameters & Method adopted \\
\hline $\mathrm{pH}$ & $\mathrm{pH}$ meter \\
\hline Electric Conductivity & Conductivity Meter \\
\hline Dissolved Oxygen & Winkler's method \\
\hline Chlorides & Argentometric method \\
\hline Total Alkalinity & Titrimetric method \\
\hline Nitrates & Phenol disulfonic method \\
\hline Sodium & Flame photometric method \\
\hline Potassium & Flame photometric method \\
\hline Calcium Hardness & EDTA Titrimetric method \\
\hline Magnesium Hardness & EDTA Titrimetric method \\
\hline Total Hardness & EDTA Titrimetric method \\
\hline Total Dissolved solids & Gravimetric method \\
\hline
\end{tabular}

Table 1: Physico-chemical properties estimation methods.

dissolved solids present in the water [6]. The electric conductivity varies from a minimum of $252 \mu \mathrm{s} / \mathrm{cm}$ at Nehru park to a maximum of $690 \mu \mathrm{s} /$ $\mathrm{cm}$ at Jogilankar basin (Table 2 and Figure 3). Nehru park basin shows optimal quantity of dissolved oxygen $7.5 \mathrm{mg} . \mathrm{L}^{-1}$ while Telebal basin and Nigeen basin shows $6.6 \mathrm{mg} . \mathrm{L}^{-1}$ each which projects some pollution in this part of the lake. Nishat basin has dissolved oxygen $5.8 \mathrm{mg} . \mathrm{L}^{-1}$ that is moderately polluted and the minimum range of dissolved oxygen was observed at Jogilankar basin was 2.5 mg.L ${ }^{-1}$ (Table 2 and Figure 4). The decrease in the value of dissolved oxygen may be due to hyper eutrophication condition of lake which is the result of high nutrient accumulation. The lower value of dissolved oxygen at Jogilankar basin was due to cumulative effect of human activities like dumping of organic wastes or other residential outlet wastes flowing into lake [7]. Depletion of dissolved oxygen in water probably is the most important indicator of certain forms of water pollution [8]. Maximum concentration of chloride was observed at Jogilankar basin which is $7.44 \mathrm{mg} . \mathrm{L}^{-1}$ (Table 2 and Figure 4), which can be correlated to high electric conductivity values of Jogilankar basin. Substantially higher levels of chloride tend to imply contamination by human activities, use of road salt, discharges from water softeners, human or animal waste disposal, leachate from landfills, and other activities. The minimum concentration of chloride ions was observed at Telebal basin 4.25 mg.L $\mathrm{L}^{-1}$ (Table 2 and Figure 4). The chloride is also an important indicator of pollution [9].

The alkalinity at Jogilankar site was maximum $220 \mathrm{mg} \cdot \mathrm{L}^{-1}$ and the lowest value was recorded at Nehru park basin (110mg. $\left.\mathrm{L}^{-1}\right)$. The high alkalinity is a function of ion exchange, that is calcium ions are replaced by sodium ions which later contributed to alkalinity [10]. Bicarbonates represent the major form of alkalinity in natural waters and its main sources include the partitioning of $\mathrm{CO}_{2}$ from the atmosphere and the weathering of carbonate minerals in rocks and soil (Table 2 and Figure 5). Nitrate concentration varies from $25 \mathrm{mg} . \mathrm{L}^{-1}$ (maximum) observed at Jogilankar basin to $16 \mathrm{mg} . \mathrm{L}^{-1}$ (minimum) observed at Nishat basin. All the sites had a high value of nitrates. The main source of nitrates is the run-off, nitrogen fertilizers used for agriculture practices and decomposition of organic matter. The higher inflow of water and consequent land drainage cause high value of Nitrate [11-13].

The maximum concentration of sodiumions was observed at Jogilankar $16.7 \mathrm{ppm}$ and minimum concentration $6.22 \mathrm{ppm}$ at Nehru park basin. Potassium concentration was much higher at Jogilankar basin 9.6 ppm while minimum was at Telebal basin 1.25 ppm (Table 2 and Figure 6). On comparing the sodium and potassium concentration of all the five basins collectively, the result depicts that sodium concentration is higher than potassium concentration. The maximum calcium concentration was $610 \mathrm{ppm}$ at Telebal basin while minimum was $248 \mathrm{ppm}$ at Nehru park basin (Table 2 and Figure 5). Calcium is also reported to form the most abundant ions in fresh water $[11,14]$. The magnesium concentration varies from $134 \mathrm{ppm}$ (minimum) at Telebal basin to $266 \mathrm{ppm}$ (maximum) at Nigeen basin (Table 2 and 
Citation: Lone JF, Rasoo A, Unnisa SA (2017) Assessment of Physico-Chemical Parameters of Water in Kashmir Region with Reference to Dal Lake. J Environ Anal Toxicol 7: 435. doi: 10.4172/2161-0525.1000435

Page 3 of 4

\begin{tabular}{|c|c|c|c|c|c|c|}
\hline S. No & Parameter & Telebal basin & Jogilankar basin & Nishat basin & Nigeen basin & Nehru park basin \\
\hline 1 & $\mathrm{pH}$ (scale 1-14) & $6.4 \pm 0.11$ & $6.7 \pm 0.06$ & $4.5 \pm 0.01$ & $6.9 \pm 0.03$ & $7.1 \pm 0.01$ \\
\hline 2 & Conductivity $\left(\mu\right.$ Siemens $\left.\mathrm{cm}^{-1}\right)$ & $527 \pm 0.11$ & $690 \pm 0.66$ & $289 \pm 0.06$ & $471 \pm 0.06$ & $252 \pm 0.01$ \\
\hline 3 & Dissolved oxygen (mg. $\left.\mathrm{L}^{-1}\right)$ & $6.6 \pm 0.11$ & $2.5 \pm 0.66$ & $5.8 \pm 0.11$ & $6.6 \pm 0.33$ & $7.5 \pm 0.40$ \\
\hline 4 & Chlorides (mg. $\left.\mathrm{L}^{-1}\right)$ & $4.25 \pm 0.03$ & $7.44 \pm 0.33$ & $4.30 \pm 0.66$ & $5.31 \pm 0.45$ & $5.31 \pm 0.11$ \\
\hline 5 & Total Alkalinity (mg. $\mathrm{L}^{-1}$ ) & $170 \pm 0.11$ & $220 \pm 0.66$ & $170 \pm 0.66$ & $180 \pm 0.33$ & $110 \pm 0.45$ \\
\hline 6 & Nitrates $\left(\mathrm{mg} \cdot \mathrm{L}^{-1}\right)$ & $18 \pm 0.11$ & $25 \pm 0.66$ & $16 \pm 0.33$ & $20 \pm 0.33$ & $21.33 \pm 0.66$ \\
\hline 7 & Sodium (ppm) & $7.11 \pm 0.03$ & $16.7 \pm 0.33$ & $7.22 \pm 0.66$ & $9.4 \pm 0.66$ & $6.22 \pm 0.11$ \\
\hline 8 & Potassium (ppm) & $1.25 \pm 0.11$ & $9.6 \pm 0.66$ & $1.34 \pm 0.33$ & $2.04 \pm 0.33$ & $1.3 \pm 0.11$ \\
\hline 9 & Calcium Hardness (ppm) & $610 \pm 0.44$ & $400 \pm 0.66$ & $336 \pm 1.03$ & $384 \pm 085$ & $248 \pm 0.44$ \\
\hline 10 & Magnesium Hardness (ppm) & $160 \pm 0.33$ & $200 \pm 0.45$ & $134 \pm 0.11$ & $266 \pm 0.66$ & $192 \pm 1.00$ \\
\hline 11 & Total Hardness (ppm) & $770 \pm 0.33$ & $600 \pm 0.66$ & $470 \pm 1.02$ & $650 \pm 1.12$ & $440 \pm 0.66$ \\
\hline 12 & Total dissolved solids (ppm) & $780 \pm 0.66$ & $1488 \pm 1.12$ & $680 \pm 0.66$ & $2248 \pm 0.45$ & $476 \pm 0.33$ \\
\hline
\end{tabular}

Table 2: Physico-chemical properties at different selected sites.

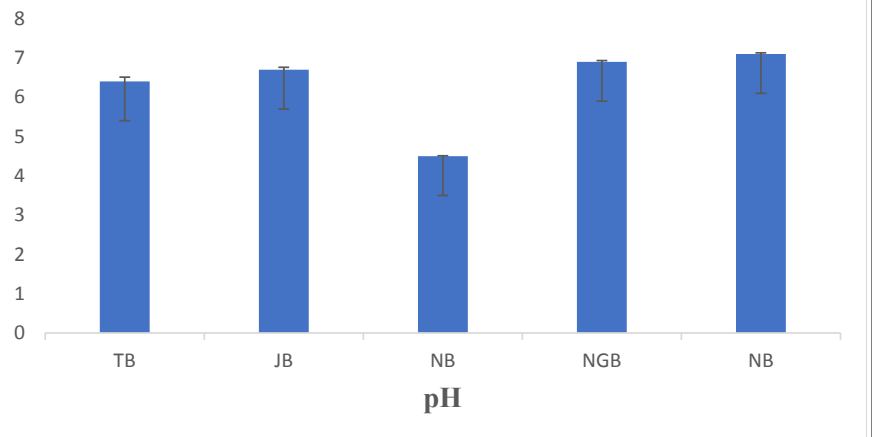

Figure 2: Comparison of Five Basins with respect to their $\mathrm{pH}$.

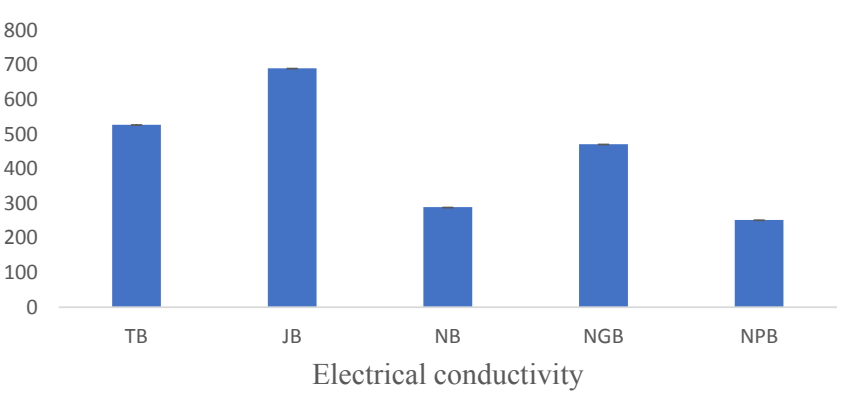

Figure 3: Comparison of five basins with respect to their Electric conductivity.

Figure 5). Maximum hardness $770 \mathrm{ppm}$ was observed from Telbal basin while minimum was at Nehru Park basin $440 \mathrm{ppm}$. Nigeen basin had the highest range of Total dissolved solids $2248 \mathrm{mg} \mathrm{L}^{-1}$ followed by Jogilankar basin $1488 \mathrm{mg} \mathrm{L}^{-1}$. TDS is the measure of total inorganic as well as organic substances suspended in water. Nehru park basin had the lowest range of TDS $476 \mathrm{mg} \mathrm{L}^{-1}$ as shown in Table 2 and Figure 7.

\section{Conclusion}

As per the study and results pertaining to the different basins, the increasing disturbances from the various anthropogenic sources are

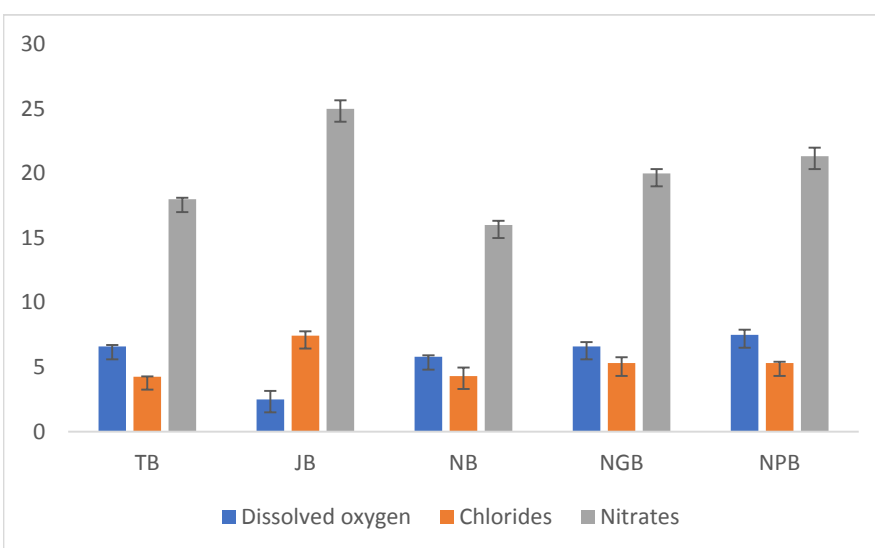

Figure 4: Showing comparison of five basins with respect to their $\mathrm{DO}, \mathrm{Cl}$, Nitrates.

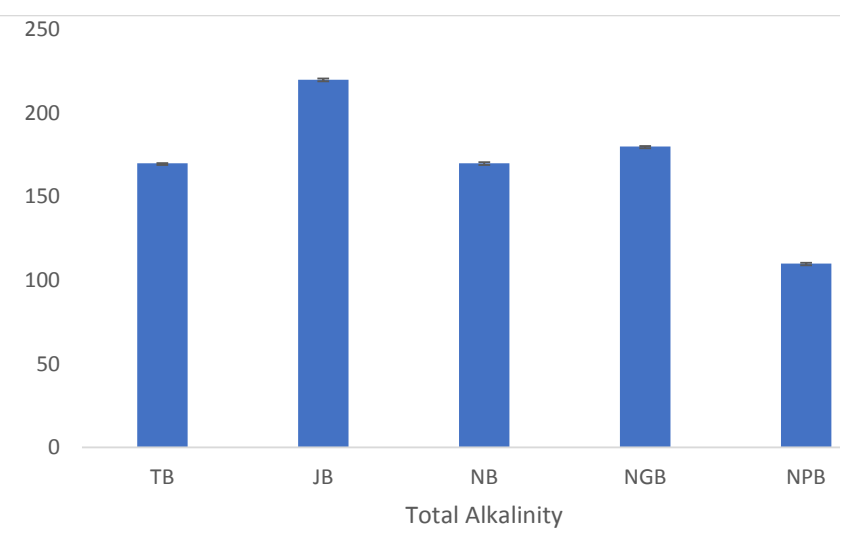

Figure 5: Comparison of five basins with respect to their Total Alkalinity.

cause of deterioration of the water quality to great extent. Telebal and Jogilankar basin in particular were observed to be more affected by the pollution sources arising from tourism and sewage disposal. Besides this, the condition of other basins seems to be deteriorating because of increasing pressure of tourism and the people living around the lake. For preventing and controlling the destruction of the Lake, various 
Citation: Lone JF, Rasoo A, Unnisa SA (2017) Assessment of Physico-Chemical Parameters of Water in Kashmir Region with Reference to Dal Lake. J Environ Anal Toxicol 7: 435. doi: 10.4172/2161-0525.1000435

Page 4 of 4

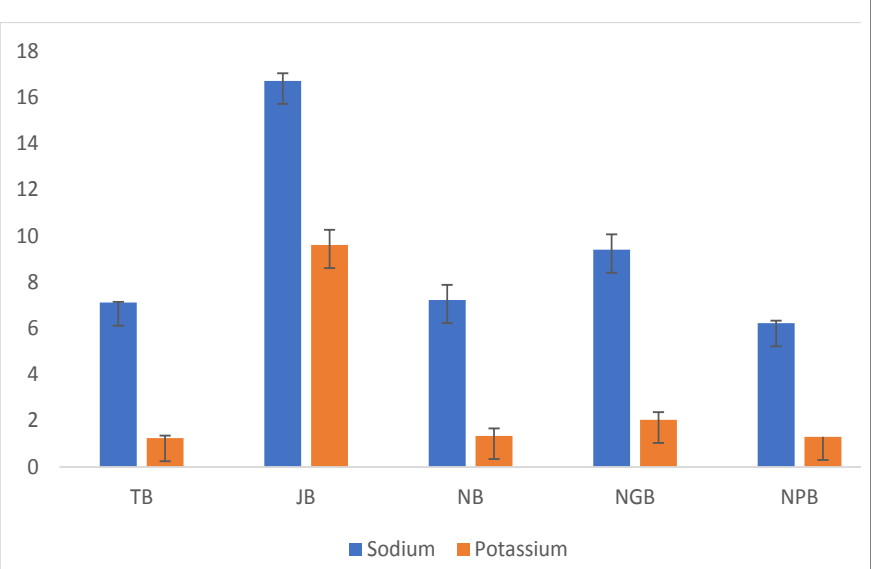

Figure 6: Showing comparison of five basins with respect to their $\mathrm{Na}$ and $\mathrm{K}$.

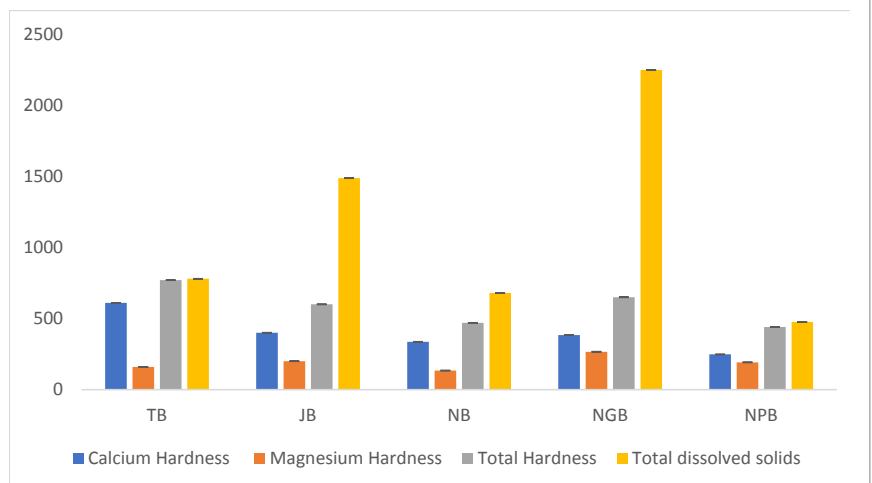

TB: TeleBal Basin; JB: Jogilankar Basin; NB: Nishat Basin; NGB: Nigeen Basin; NPB: Nehru Park Basin

Figure 7: Showing comparison of five basins with respect to their Total hardness, Ca hardness, Mg hardness and total dissolved solids.

steps should be taken as responsibilities to the authorities like Tourists should be made aware of not to pollute the lake. Treatment of sewage should be done at various basins. Houseboats at Nehru Park and Nishat
Basins should be instructed not to discharge their waste in the water as it results to further detoriration of the lake. Steps should be taken to aware public and tourists regarding pollution.

\section{Acknowledgement}

The authors would like to thank the School of Studies in Botany, Jiwaji University, Gwalior for providing laboratory facilities in carrying out the work.

\section{References}

1. Ul-yaqoob K, Pandit AK, Wani A (2007) Comparative physiochemical limnology of three lakes of Kashmir Himalaya. Proceedings of Taal 2007: The $12^{\text {th }}$ World Lake Conference, pp: 1922-1927.

2. Qadri MY, Yousuf AR (1980) Limnological studies on Lake Malpur Sar 1. The Biotope Geobios, pp: 117-119.

3. Kundankar MR, Sarwar SG, Shah MA (1995) Limnological characteristics of Hazratbal basin of Dal Lake (1992-93). Technical report- submitted to Government of Jammu and Kashmir.

1. Murtaza S, Hussain SA, Ali S (2011) Impact of Pollutants on Physico-Chemical Characteristics of Dal Lake under Temperate Conditions of Kashmir. Environ Ecol 29: 1714-1716.

2. Lijklema L (1994) Nutrient dynamics in shallow lakes: effects of changes in loading and role of sediment-water interactions. Hyrobiol 275: 335-348.

3. Gupta S, Maheto A, Roy P, Datta JK, Saha RN (2008) Geochemistry of groundwater Burdwan district, West Bengal, India. Environ Geol 3: 1271-1282.

4. Mustapha MK (2003) A pre-impoundment study of limno-chemical conditions of Oyunlake in Ilorin, Kwara state, Nigeria. Afr J Appl Zool Environ Boil 5: 44-48.

5. Srivastava N, Harit GH, Srivastava R (2009) A study of physico-chemical characteristics of lakes around Jaipur. Indian J Environ Biol 30: 889-894.

6. Khare SL, Paul SR, Dubey A (2007) A Study of water quality of Khomph-Niwari Lake at Chhatarpur, MP. Nat Env Poll Tech 6: 539-540.

7. Sharma G, John RV (2009) Study of physico-chemical parameters of waste water from dyeing units in Agra city. Poll Res 28: 439-442.

8. Thilaga A, Subhashini, Sobhana S, Kumar KL (2005) Studies on nutrient content of the Ooty Lake with reference to pollution. Nat Env Poll Tech 2: 299302

9. Garg RK, Rao RJ, Uchchariya D, Shukla G, Saksena DN (2010) Seasonal variations in water quality and major threats to Ramsagar reservoir, India. Afr J Environ Sci Technol 4: 061-076.

10. Munawar M (1970) Limnological studies of freshwater ponds of Hyderabad, India. Hydrobiol 35: 127-162.

11. Pandit AK (1993) Dal lake ecosystem in Kashmir Himalaya: Ecology and Management. In: Ecology and Pollution of Indian Lakes and Reservoirs, Ashish Publishing House, New Delhi, India, pp: 131-202. 